\title{
Japan reviews cose of nuclear reprocessing
}

Tokyo. Massive cost overruns in the construction of Japan's nuclear waste reprocessing facility in Aomori Prefecture in northern Japan have necessitated redesign and scaling back of the plant, pushing back completion by three years to 2003 .

A joint announcement last month by Japan Nuclear Fuel Ltd (JNFL), the company that is building the facility, and the Federation of Electric Power Companies, revealed that the estimated cost of construction has doubled to $¥ 1,660$ billion (\$US16 billion), further shaking public confidence in

Construction of the plant, which began at Rokkasho village in 1989, was originally expected to cost $¥ 840$ billion, an estimate based on the construction cost of France's reprocessing plant at $\mathrm{La}$ Hague. JNFL claims that the increased cost is due to rising material prices, combined with the expense Japan's troubled plutonium policy.

of making the facility safe against earthquakes.

Despite doubling in price, the redesigned plant will be significantly smaller than the original. It will incorporate a single-stage process for separating uranium from plutonium rather than the original two-stage process, six rather than nine containers for high-level waste, and combined rather than separate facilities for evaporating and drying low-level liquid waste.

JNFL claims that the new design will have the same processing capacity as the original, namely 4.8 tonnes of plutonium per year from 800 tonnes of high-level waste. But industry observers such as Mika Obayashi of the Citizen's Nuclear Information Center in Tokyo are sceptical, given the reduction in the scale of the plant.

The cost overruns will be passed on to the power generation industry, and are expected

\section{French genome pioneer goes private}

Paris. Daniel Cohen, the French genome scientist, was due to announce this week that he is to resign as director of the Centre d'Etudes du Polymorphisme Humain (CEPH) in Paris, and merge his research group with the French biotechnology company Genset to create a world-class genome company.

Cohen, who will become general manager of genome research, says that Genset, with about 170 staff, will be the only European company large enough to compete with US rivals such as Human Genome Sciences, which has about the same number of staff.

Genset, which plans to seek a public flotation in the United States later this year, was created in 1989, and has since become a leader in the manufacture of oligonucleotides. It also carries out research in gene regulation, gene sequencing and computer analysis. Cohen's arrival will allow it to develop a comprehensive approach to genomics "from research to drugs", says Pascal Brandys, its chief executive officer.

In particular, Genset's business strategy will be to identify genes and use them to develop small-molecule therapeutics for the treatment of a broad range of diseases including cancer. The development of therapeutics would be carried out in collaboration with large drug companies.

The attraction of Genset, says Cohen, is its "industrial culture" and high-technology approach. He claims that its "leading-edge" facilities will allow "brute force" sequencing leading to the rapid analysis of regions of the genome of interest.

Cohen adds that his departure from CEPH will put an end to the controversies that have dogged him over alleged conflicts of interests between his position at the centre and his involvement in private biotechnology companies (see Nature 368, 1775; 1994). "Now I am private," he says.

But Jean Dausset, the founder and president of the centre, describes Cohen's departure as a major loss and the "end of an era". Cohen has been director of the centre since it was created in 1982 by Dausset, the 1980 Nobel joint prizewinner in medicine or physiology, to carry out genetic mapping for the study of multigenic diseases.

Indeed, CEPH has since made an important contribution to genetics by making DNA from a large group of families freely available to laboratories worldwide. Later, in a joint venture with the French Muscular Dystrophy Association (AFM), it created the Généthon laboratory, whose successes include physical and genetic maps of the entire human genome.

CEPH will now abandon genetic mapping, but will continue to use maps to identify genes for disease susceptibility. Dausset says that relaunching CEPH's activities will depend on finding a geneticist of international renown to lead the centre. But he accepts that Cohen was "right to leave", given that CEPH could never provide him with the financial resources needed for his ambitious plans in genome research.

Nevertheless, the separation between Cohen and CEPH has not been without its problems. One issue that remains to be resolved is the fate of the techniques and materials developed by Cohen at CEPH. Dausset says that there is a "real risk" that Cohen will take most of CEPH with him when he leaves. Both men are negotiating the extent of transfers of staff and resources. to cost the industry roughly $¥ 80$ billion a year in increased reprocessing charges. Altogether, the cost of reprocessing fuel is calculated to add $¥ 1$ to the cost of generating each kilowatt hour of electricity, which is already about 40 per cent more expensive than in France.

The effect of the cost overruns and delays is likely to add $¥ 2,000$ billion (about US $\$ 20$ billion) to the total cost of establishing the nuclear fuel cycle within Japan, a central plank of Japan's long-term nuclear energy strategy. Japan currently has to use overseas facilities in France and the United Kingdom to reprocess its nuclear fuel.

This latest announcement adds to the woes of Japan's nuclear industry, already reeling after the shut-down in December of the experimental fast breeder reactor Monju in Fukui Prefecture in western Japan, and an attempted cover-up of the seriousness of the accident (see Nature 379, 196; 1996). This incident, which has brought into question both the technical feasibility of the FBR programme and the competence and trustworthiness of the administering bodies, has cast a shadow over the government's entire plutonium policy.

On the same day as the announcement on the Rokkasho reprocessing plant, the governors of three prefectures - Fukui, Niigata and Fukushima - visited the Prime Minister's office and the Ministry of International Trade and Industry (MITI) to urge the government to review the entire longterm nuclear energy programme. They expressed particular concern over the plan to burn mixed uranium-plutonium fuel (MOX) in conventional light water reactors (LWRs) from the late 1990s.

The three indicated that they will not permit the relicensing of reactors in their prefectures to burn MOX until the investigation into the Monju accident is completed. Almost two-thirds of Japan's 48 operating LWRs are in these three prefectures, including the two for which relicensing applications are expected to be made first. Neither the government nor the power utilities admits to any changes in the MOX policy.

Apart from domestic political opposition and popular distrust of the operating authorities, there is also concern among the international community about Japan's growing stockpile of plutonium. Despite the government's policy of not stockpiling plutonium - which could possibly be used to build nuclear weapons - its own figures show that plutonium stocks will rise from the present level of a few tonnes to about 70 tonnes by 2010, about half this figure representing imports of plutonium from Europe.

This estimate will no doubt be reduced because of the delays in the opening of the plant in Aomori.

Stephen Barker 